\title{
Long term effects of reduced fertilizer rates on millet yields and soil properties in the West-African Sahel
}

\author{
Alexis M. Adams • Adam W. Gillespie • Gourango Kar • \\ Saidou Koala $\cdot$ Badiori Ouattara $\cdot$ Anthony A. Kimaro $\cdot$ Andre Bationo • \\ P. B. Irenikatche Akponikpe $\cdot$ Jeff J. Schoenau $\cdot$ Derek Peak
}

Received: 22 December 2015/ Accepted: 30 May 2016/Published online: 14 July 2016

(C) The Author(s) 2016. This article is published with open access at Springerlink.com

\begin{abstract}
Microdosing, the point-source application of a reduced fertilizer rate within 10 days of sowing, has increased short-term crop yields across the Sahel and is being actively scaled up as an agronomic practice. However, there is no information on the longterm effects of the technique upon soil fertility. To rectify this, this study used soil samples from the International Crop Research Institute for the SemiArid Tropics in Sadore, Niger, to assess the effects of 16 years of a reduced fertilizer rate of $15 \mathrm{~kg} \mathrm{~N}$ and $4.4 \mathrm{~kg} \mathrm{P} \mathrm{ha}{ }^{-1}$ compared to unfertilized soil and a recommended rate of $30 \mathrm{~kg} \mathrm{~N}$ and $13.2 \mathrm{~kg} \mathrm{P} \mathrm{ha}^{-1}$ upon millet yield trend, soil chemical properties, and soil organic matter quality. The interaction of fertilizer with crop residue and manure amendments at 300 ,
\end{abstract}

A. M. Adams · A. W. Gillespie - G. Kar ·

J. J. Schoenau · D. Peak $(\square)$

Department of Soil Science, University of Saskatchewan,

51 Campus Drive, Saskatoon SK, S7N 5A8, Canada

e-mail: jdp648@mail.usask.ca

A. W. Gillespie

Canadian Light Source Inc., 44 Innovation Boulevard,

Saskatoon SK S7N 2V3, Canada

S. Koala

International Center for Tropical Agriculture (CIAT),

P.O Box 823-00621, Nairobi, Kenya

B. Ouattara

Institute of Environment and Agricultural Research

(INERA), 04 BP: 8645, Rue Guisaga, Ouagadougou,

Burkina Faso
900, and $2700 \mathrm{~kg} \mathrm{ha}^{-1}$ was also assessed. Compared to unfertilized soil, the reduced fertilizer rate improved yield by $116 \%$ but did not increase total $\mathrm{N}$ or available $\mathrm{P}$. The recommended rate doubled available $\mathrm{P}$ and increased total $\mathrm{N}$ by $27 \%$, but resulted in slightly lower $\mathrm{pH}$ compared to the reduced rate. Yield trends were negative for both fertilizer treatments, indicating mineral fertilizer alone is not sustainable at Sadore. Crop residue or manure addition at $2700 \mathrm{~kg} \mathrm{ha}^{-1}$ with fertilizer did not improve SOC but buffered $\mathrm{pH}$ by 0.3 units, provided nutrients beyond $\mathrm{N}$ and $\mathrm{P}$, and changed the forms $\mathrm{C}$ and $\mathrm{N}$ functional groups in soil organic matter.

\author{
A. A. Kimaro \\ World Agroforestry Centre (ICRAF), ICRAF-Tanzania \\ Programme, P. O. Box 6226, Dar-Es-Salaam, Tanzania
}
A. Bationo
Action for Integrated Rural Development (AFIRD),
KA98 46 G3121 Accra, Ghana
P. B. I. Akponikpe
Department of Natural Resources Management,
University of Parakou, 03 BP: 351, Parakou, Benin 
Keywords Fertilizer microdosing - Long-term sustainability $\cdot$ Soil fertility $\cdot$ Soil organic matter dynamics $\cdot$ XANES $\cdot$ NEXAFS

\section{Introduction}

Crop production is increasing at $1 \%$ per year across Sub-Saharan Africa (Chauvin et al. 2012), but is outpaced in the Sahel by a population growth rate of over $3 \%$ (World Bank 2014). Major reasons for low productivity increases include unstable rainfall patterns, low inherent soil fertility, low fertilizer use, and competition for organic inputs as fuel or for grazing (Abdoulaye and Sanders 2005). Fertilizer use is low in the Sahel because of high fertilizer costs and limited access as a result of poor infrastructure and a weak private crop input sector (Abdoulaye and Sanders 2005). Because of high fertilizer costs and uncertainty about production potential, it is often too risky for farmers to invest in applying the recommended rates of fertilizer to optimize yield (Aune and Bationo 2008). Fertilizer microdosing, which is the application of about half the recommended rate of fertilizer near the seedling within 10 days of sowing (Twomlow et al. 2008), has potential to ease smallholder fertilizer use constraints in the Sahel. Microdosing has been found in the short term to substantially increase yields and nutrient use efficiency, while simultaneously increasing income by reducing farmer investment and risk (Twomlow et al. 2008; Aune and Ousman 2011; Bagayoko et al. 2011; Sime and Aune 2014). While the short-term benefits of microdosing in the Sahel are now known, there has been little research on the long-term effects of microdosing on soil fertility and agroecosystem sustainability.

There is some concern that microdosing may not be sustainable over the long term due to eventual soil nutrient depletion, especially without joint application of organic matter or return of crop residues (Aune and Bationo 2008; Twomlow et al. 2008). Alternatively, researchers have suggested that microdosing may lead to improved long-term soil productivity compared to unfertilized soil because of increased crop residue inputs and thus soil organic carbon (SOC) (Aune and Bationo 2008; Bagayoko et al. 2011). Long-term research is essential to assess microdosing as a sustainable soil fertility management, but the effect of microdosing on nutrient cycling and soil organic matter (SOC) composition has not yet been studied. In the current research, the effects of 16 years of reduced $\mathrm{N}$ and $\mathrm{P}$ fertilizer application rates (consistent with the microdose rate currently used for millet) were analyzed to provides unique information on the long-term impact of microdosing on Sahelian soils.

There is potential for the sustainability of microdosing to be improved with joint application of crop residues or manure as part of integrated soil fertility management (ISFM) (Vanlauwe et al. 2010). For example, long-term application of manure in the Sahel has been found to sustain yields (Kihanda and Warren 2012) and increase SOC and soil $\mathrm{pH}$ compared to fertilizer alone (Bado et al. 2012). At long-term research sites in the Sahel, crop residue amendment was shown to improve root growth and buffer against soil acidification, while also increasing SOC and soil nutrient availability (Geiger et al. 1992; Kibunja et al. 2012). Combining fertilizer additions with either crop residues or manure alters the soil $\mathrm{C}: \mathrm{N}$ ratio, resulting in immobilization that reduces nitrogen losses, while at the same time speeding up the breakdown of organic inputs to increase C stability (Gentile et al. 2013). Unfortunately, crop residue and manure are both in low supply for smallholders (Abdoulaye and Sanders 2005; Bationo et al. 2012).

Measuring $\mathrm{C}$ and $\mathrm{N}$ content of soil is an important step in determining soil fertility. However, total concentrations are often less important than the chemical form (species) that is present. Spectroscopic techniques that can directly measure the different chemical forms of organic $\mathrm{C}$ and $\mathrm{N}$ in soils provide novel information on how nutrients and organic matter $(\mathrm{OM})$ are cycling under different management practices. The forms of $\mathrm{C}$ and $\mathrm{N}$ that are in soil organic matter (SOM) reflect different points in the decomposition sequence from fresh plant material to decomposed and stabilized materials (Wickings et al. 2012). The newly developed soil continuum model (Lehmann and Kleber 2015) considers soil organic matter as having chemical structure and turnover times that are dictated by aggregation with soil, sorption on mineral surfaces, and biological transformations into biopolymers of varying size. All of these processes leave a chemical signature in SOM. Organic C and N species found in fresh plant material indicate limited microbial breakdown of organic inputs, whereas microbial decomposition results in the formation of 
microbially-derived $\mathrm{C}$ and $\mathrm{N}$ groups and biopolymers that can be identified in the soil organic matter (Gillespie et al. 2014a).

As the fertilizer microdosing technique is now being scaled up throughout the Sahel as a result of both development research and extension activities, it is important to quantify the possible negative effects of reduced fertilizer application. Accordingly, the objective of this study was to determine the long-term effects of reduced rates of fertilizer on soil fertility and $\mathrm{C}$ and $\mathrm{N}$ dynamics, alone and in combination with crop residue and manure application. We are using the Sadore, Niger research trials as a worst case scenario; 16 years of intensive monoculture under controlled conditions. Our methods included analyzing yield trends, soil chemical properties, and $\mathrm{C}$ and $\mathrm{N} \mathrm{K}$-edge XANES spectra of soil samples to assess the overall changes in fertility that accompany reduced fertilizer rates. We hypothesized that the reduced rate would negatively affect soil fertility and nutrient cycling compared to the recommended rate, but that application of organic matter along with manure will reduce the negative effects of the microdosed rate.

\section{Materials and methods}

\section{Site description}

The Sadore long-term research trial is managed by the Tropical Soil Biology and Fertility Institute of the International Centre for Tropical Agriculture (TSBFCIAT) at the International Crop Research Institute for the Semi-Arid Tropics (ICRISAT) in southwestern Niger. Annual precipitation at Sadore is 440-587 $\mathrm{mm}$ year $^{-1}$ and average annual temperature is 28.6. Sadore soils are classified as Arenosols, an unstable sandy soil that is low in nutrient and water holding capacity (Jones et al. 2013). Based on particle size analysis, the soil is $92 \%$ sand, with this fraction primarily medium $(40 \%)$ and fine $(37.6 \%)$ sand.

The soils provided for this study were originally part of an integrated nutrient management trial that began in 1994, and was described in detail by Akponikpe et al. 2008. Briefly, the experiment is a $3^{3}$ factorial RCBD layout with three replications per treatment. Cropping was under continuous Pennisetum glaucum (millet) with varying rates of mineral fertilizer, crop residue, and farmyard manure. Mineral fertilizer treatments included a control, a reduced rate (15 kg N ha ${ }^{-1}$ and $4.4 \mathrm{~kg} \mathrm{P} \mathrm{ha}^{-1}$ ), and a recommended rate $\left(30 \mathrm{~kg} \mathrm{~N}^{-1}\right.$ and $\left.13.2 \mathrm{~kg} \mathrm{P} \mathrm{ha}^{-1}\right)$. Nitrogen was applied as calcium ammonium nitrate (CAN) 10 days after sowing (DAS) $10 \mathrm{~cm}$ from the seed via incorporation with a hand hoe. Phosphorus was applied before sowing as single super phosphate (SSP) and was hill placed and ploughed into the soil (Akponikpe et al. 2008). Both crop residue and cattle manure amendment treatments were applied at 3 rates: 300,900 , or $2700 \mathrm{~kg} \mathrm{ha}^{-1}$. Average manure nutrient contents were $1 \pm 0.05 \% \mathrm{~N}, 0.2 \pm 0.01 \% \mathrm{P}$ and $1.6 \pm 0.09 \% \mathrm{~K}$ (mean $\pm \mathrm{SD}$ ) and average crop residue nutrient contents (weighted leaf and stem content) were $0.74 \pm 0.14 \% \mathrm{~N}, 0.05 \pm 0.01 \% \mathrm{P}$ and $2.54 \pm 0.44 \%$ K (Akponikpe et al. 2008). Crop residue was applied as surface mulch and manure was broadcast and incorporated; both were added before sowing. There was no control treatment for organic amendments because even in traditional low input systems some residue is still left in the field, and passing grazing animals deposit manure in all fields (Akponikpe et al. 2008). Sowing took place after the first rain, which was most commonly in June, but in some years took place in May or July. Millet was planted at 10,000 hills ha ${ }^{-1}$ and after 2-3 weeks thinned to 30,000 plants $\mathrm{ha}^{-1}$. Hand weeding took place two to three times per cropping season to control weeds.

Soil chemical analyses

Soil samples were collected prior to sowing in 2013; three composited and well-mixed samples were taken from each plot at the $0-20 \mathrm{~cm}$ depth using an auger. A sub-sample was air-dried, ground to pass through a $2 \mathrm{~mm}$ sieve, packaged in individual airtight sealed bags, and shipped to the University of Saskatchewan. Soil samples were stored in airtight vials and analyzed for $\mathrm{pH}$, organic carbon (OC), total $\mathrm{P}$ and $\mathrm{N}$, available $\mathrm{P}$, and effective cation exchange capacity (CEC) using standard methods. Soil $\mathrm{pH}$ was measured in triplicate using a glass electrode in a 2:1 water: soil suspension (Hendershot et al. 2008). The LECO-C632 carbon determinator (LECO@ Corporation 1987) was used to analyze two $0.3 \mathrm{~g}$ replicates of each soil sample for $\mathrm{OC}$ concentration. Total $\mathrm{N}$ and $\mathrm{P}$ were measured in triplicate according to the acid block digestion method of Thomas et al. (1967). Digests were then allowed to 
cool to room temperature, diluted and analyzed on an auto-analyzer. A standard soil of known total $\mathrm{P}$ concentration was used for quality control. Extractable, available $\mathrm{P}$ and effective CEC were determined using a Mehlich-3 extraction because the Mehlich-3 extraction is applicable to tropical acidic soils and extracts multiple elements of interest to this study (Ziadi and Tran 2008). Available P was determined from the Mehlich-3 extracted soil solution using an auto-analyzer and CEC was estimated by measuring the concentrations of exchangeable $\mathrm{Ca}^{2+}, \mathrm{Mg}^{2+}, \mathrm{Na}^{+}$, and $\mathrm{K}^{+}$cations in vacuum filtered Mehlich-3 solutions on a Microwave Plasma Atomic Absorption Spectrometer (MP-AES 4100 Agilent Technologies).

\section{X-ray absorption spectroscopy}

$\mathrm{C}$ and $\mathrm{N}$ speciation was determined by measuring X-ray Absorption Near-Edge Structure (XANES) at the $\mathrm{C}$ and $\mathrm{N} K$-edges using the Spherical Grating Monochromator (SGM) beamline 11ID-1 at the Canadian Light Source in Saskatoon, Saskatchewan, Canada. Samples were prepared by suspending a small amount of the soil sample with water, pipetting onto Au-coated Si wafers attached to the sample holder using double-sided carbon tape, and allowing to air dry. The highest \%OC replicate for each treatment was selected for XANES measurement to maximize the signal. Data was collected using slew scanning mode to minimize radiation damage to the sample (Gillespie et al. 2015). An average of 60 scans were taken per sample at a new spot on the sample for each scan. The beam line exit slit was set to $25 \mu \mathrm{m}$ and partial fluorescence yield was collected using a silicon drift detector (AmpTek). The XANES spectral features for $\mathrm{C}$ and $\mathrm{N}$ types were identified from published diagnostic peaks of reference compounds (Leinweber et al. 2010; Myneni 2002; Urquhart and Ade 2002). For C spectra, assignments were: (1) aromatic $\mathrm{C}$ at $285 \mathrm{eV}$; (2) ketone at $286.6 \mathrm{eV}$; (3) phenolic at $287.1 \mathrm{eV}$; (4) carboxylic at $288.6 \mathrm{eV}$; and (5) carbohydrate hydroxyl at $289.6 \mathrm{eV}$. For $\mathrm{N} K$-edge spectra, the assignments were: (1) pyridinic- $\mathrm{N}$ at $398.7 \mathrm{eV}$, (2) amide- $\mathrm{N}$ (i.e., protein $\mathrm{N}$ ) at $401.2 \mathrm{eV}$, (3) pyrrolic-N at $402.5 \mathrm{eV}$, (4) $\mathrm{N}$-bonded aromatics at $403.5 \mathrm{eV},(5)$ inorganic nitrate at $405.3 \mathrm{eV}$ and (6) alpha amino-N at $406 \mathrm{eV}$.

Citric acid was used for calibration at the $\mathrm{C} K$-edge where the $\mathrm{C} 1 \mathrm{~s}(\mathrm{C}=\mathrm{O}) \rightarrow \pi^{*}{ }_{\mathrm{C}=\mathrm{O}}$ transition at $288.8 \mathrm{eV}$ was used for energy calibration.
Normalization to incident flux $\left(\mathrm{I}_{0}\right)$ was carried out by recording the scattering intensity from a freshly sputtered (carbon free) Au surface across the C $-K$ edge (Gillespie et al. 2015). The $\mathrm{N} K$-edge data was calibrated to the $v=0$ vibration of interstitial $\mathrm{N}_{2}$ gas (at $400.8 \mathrm{eV}$ ) in solid-state ammonium sulfate (Gillespie et al. 2008).

Data analyses

Grain yield data, collected for each year of the trial, was analyzed using PROC MIXED in SAS (Version 9.4; SAS Institute, Cary, NC) to calculate the regression of yield (y) on time (x). This analysis was conducted to determine the yield trend for different fertility treatments. Rainfall data from Sadore was also regressed over time using PROC MIXED to determine the influence of annual precipitation on yield trend. Mean comparisons of soil properties were also conducted with PROC MIXED in SAS. The TukeyKramer test method of multi-treatment comparison for least significant differences (LSD) was used for mean comparison, with treatments as fixed effect and replications as block effect. Significance for yield regression and soil property mean comparison was declared at $p \leq 0.05$.

$\mathrm{C}$ and $\mathrm{N} K$-edge XANES data was processed using custom macros IGOR Pro v.6 software (Wavemetrics, Lake Oswego, OR, USA). The pre-edge region of all spectra was subtracted to remove background, and all spectra were normalized to an edge step of one. Peaks were identified according to Gillespie et al. (2014a, 2014b).

\section{Results and discussion}

Yield average and trends

Millet grain yield over time and the linear regression fit for each fertilizer rate strategy were graphed to illustrate yield response and trends (Fig. 1). Over 16 years, the millet crop yield minimum was less than $100 \mathrm{~kg} \mathrm{ha}^{-1}$ and maximum was greater than $1650 \mathrm{~kg} \mathrm{ha}^{-1}$, with the yield increasing with fertilizer rate, crop residue, and manure application. Yield was highest with the recommended fertilizer rate, but the yield response per unit of fertilizer applied (i.e. agronomic use efficiency) was greater for the reduced 
rate than for the recommended rate. The reduced fertilizer rate increased yield by $110 \%$ over the control, whereas the recommended rate increased yield by $16 \%$ compared to the reduced rate. A similar yield increase was seen in short-term microdosing trials in Africa, ranging from a 46-220\% increase from unfertilized to microdosed depending on the fertilizer rates, crops grown, and climatic conditions of the specific trial (Aune and Ousman 2011; Bagayoko et al. 2011). Although fertilizer greatly improved yield in the initial years of application, yield trend was negative over time at both fertilizer rates (Fig. 1). There was no significant relationship between yield and time for the control fertilizer treatment. The regressions of annual precipitation on time, and mean yield for each fertilizer rate on annual precipitation were not significant. This indicates that precipitation is not predominantly responsible for the negative yield trend. Other Sahel studies also reported declining yield over time with long-term fertilizer application (Bado et al. 2012; Kibunja et al. 2012). Decreasing soil fertility, as well as increased weed and disease pressure with continuous millet cropping may explain the yield decline. The negative yield trend over time is significant but the model only explains $40 \%$ of variation, thus caution should be exercised when drawing general conclusions from this figure on fertilizer use in the Sahel. Other events such as severe droughts, which occurred in 2005, 2010, and 2012, or locust infestation may explain some yield variability.

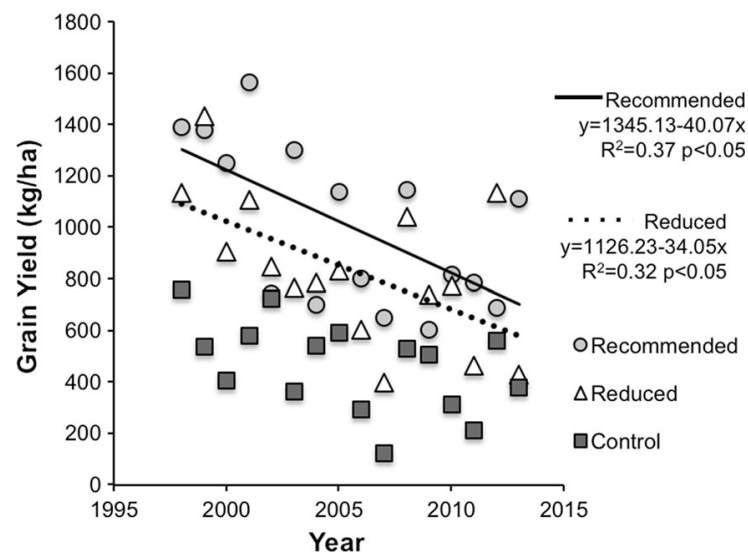

Fig. 1 Regression of millet yield versus time (year) for each fertilization strategy at Sadore site. Regression for control fertilizer treatment was not significant, thus no regression equation was included
Another concern is that annual precipitation may not be nearly as important to yields as is the timing of rainfall events. Although other factors must be considered in analyzing yield over time, the significant negative yield trend for both fertilizer rates suggests that neither treatment is sustainable.

Effect of fertilizer rate on soil chemical properties

Results for soil $\mathrm{pH}, \mathrm{CEC}$, and organic carbon content are shown in Table 1 as an average of all samples for a given fertilizer treatment. Long-term fertilizer application led to a significant decrease in soil $\mathrm{pH}$ from an average of 5.3 when no fertilizer was used, to 5.0 at the recommended rate. Similar $\mathrm{pH}$ decreases have been observed in other long-term fertilizer application research and were attributed to acidity produced in the nitrification of ammonium to nitrate (Manna et al. 2005; Bado et al. 2012; Caires et al. 2015). The decrease in $\mathrm{pH}$ of $0.3 \mathrm{pH}$ units is not large, but in sandy soils such as these with extremely low CEC and OC it may be enough to decrease exchangeable base cations, and increase exchangeable $\mathrm{Al}^{+3}$ content in the soil solution. The reduced rate of fertilizer causes less soil acidification than the higher rate and thus may be less detrimental to soil productivity.

Soil CEC was very low, and was not affected by fertilizer rate (Table 1) or improved with addition of crop residue or manure. Other Sahel research has observed an increase in CEC from crop residue application (Geiger et al. 1992), but in our samples the treatment effects on both soil $\mathrm{pH}$ and $\mathrm{OC}$ were small. As CEC is more closely related to SOC content in the Sahel than it is to soil clay content or mineralogy (Bationo et al. 2007), higher rates of organic matter input than used in these trials may be required to significantly improve CEC.

Soil organic carbon was very low overall, ranging from $0.20 \mathrm{OC}$ to $0.31 \% \mathrm{OC}$, and mineral fertilizer treatments did little to increase SOC (Table 1). Application of fertilizer at either the reduced or recommended fertilizer rate statistically increased OC compared to the control, but only by $0.02-0.03 \%$. The slight OC increase with fertilizer is likely due to increased biomass production (Alvarez 2005). SOC may not increase greatly with fertilizer addition because fertilizer $\mathrm{N}$ also stimulates organic matter 
Table 1 Soil $\mathrm{pH}, \mathrm{CEC}$, and TOC for samples sorted by fertilizer rate in the surface $(0-20 \mathrm{~cm})$ soil at the Sadore long-term research site

\begin{tabular}{llll}
\hline Fertilizer & $\mathrm{pH}$ & $\begin{array}{l}\mathrm{CEC} \\
\left(\mathrm{cmol}_{\mathrm{c}} \mathrm{kg}^{-1}\right)\end{array}$ & $\begin{array}{l}\text { Organic } \\
\text { carbon }(\%)\end{array}$ \\
\hline Control $^{\mathrm{a}}$ & $5.3 \mathrm{a}^{\mathrm{b}}$ & $0.7 \mathrm{a}$ & $0.24 \mathrm{a}$ \\
Reduced & $5.1 \mathrm{~b}$ & $0.6 \mathrm{a}$ & $0.26 \mathrm{~b}$ \\
Recommended & $5.0 \mathrm{c}$ & $0.6 \mathrm{a}$ & $0.27 \mathrm{~b}$ \\
\hline
\end{tabular}

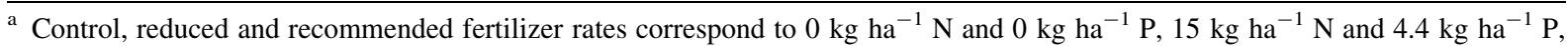
$30 \mathrm{~kg} \mathrm{ha}^{-1} \mathrm{~N}$ and $13.2 \mathrm{~kg} \mathrm{ha}^{-1} \mathrm{P}$ respectively applied per year for 16 years as calcium ammonium nitrate (CAN) and single super phosphate (SSP) fertilizer. All the crop residue and manure treatments are averaged for each fertilizer rate

b Means within a column followed by the same letter are not significantly different $(p \geq 0.05)$ using Tukey test for LSD

degradation (Chivenge et al. 2010). Although SOC is low, it is not declining; SOC measured in the top $20 \mathrm{~cm}$ of the soil at the start of the experiment was $0.18 \%$ OC, which is similar to current levels (Akponikpe et al. 2008). Thus, SOC decline, which has explained yield decline in other long-term field research (Manna et al. 2005), does not explain the observed yield declines.

Unexpectedly, crop residue and manure did not interact with fertilizer application to increase SOC beyond fertilizer alone. Difficulty in sequestering OC with organic inputs has been observed in other SubSaharan African long-term trials and was attributed to rapid mineralization and soil erosion from the arid climate and to continuous cultivation and a lack of OM protection in sandy soils (Yamoah et al. 2002; Janssen 2011). Trials that were successful in accumulating OC in West Africa were either (a) higher in clay content, which increased aggregation and protected SOM from decomposition (Feller and Beare 1997; Gentile et al. 2013) or (b) used manure rates two to three times higher than the maximum of this study (Nakamura et al. 2012).

Crop residues are not believed to be important inputs for SOC formation in the Sahel, as the high $\mathrm{C} / \mathrm{N}$ ratio of residues slows their humification and contribution to SOC (Ouédraogo et al. 2007). However, at this site crop residues appear to play an important role in limiting soil acidification caused by fertilizers (Table 2). This is consistent with previous Sahel research (Geiger et al. 1992). The highest crop residue treatment increased soil pH from 5.2 to 5.5 in the control, and from 4.9 to 5.2 at the reduced fertilizer rate, but did not buffer $\mathrm{pH}$ for the high rate, suggesting that this rate of fertilizer produces more acidity than the current crop residue rates can buffer.
Table 2 Effect of fertilizer and crop residue treatments on soil $\mathrm{pH}(1: 2$ soil:water extract) in the surface $(0-20 \mathrm{~cm})$ soil at the Sadore long-term research site

\begin{tabular}{lll}
\hline Fertilizer & Crop residue & $\mathrm{pH}$ \\
\hline Control $^{\mathrm{a}}$ & Low $^{\mathrm{b}}$ & $5.2 \mathrm{bc}^{\mathrm{c}}$ \\
& Medium & $5.3 \mathrm{~b}$ \\
& High & $5.5 \mathrm{a}$ \\
Reduced & Low & $4.9 \mathrm{de}$ \\
& Medium & $5.1 \mathrm{~cd}$ \\
& High & $5.2 \mathrm{bc}$ \\
Recommended & Low & $4.9 \mathrm{e}$ \\
& Medium & $5.0 \mathrm{de}$ \\
& High & $5.0 \mathrm{de}$ \\
\hline
\end{tabular}

a Control, reduced and recommended fertilizer rates correspond to $0 \mathrm{~kg} \mathrm{ha}^{-1} \mathrm{~N}$ and $0 \mathrm{~kg} \mathrm{ha}^{-1} \mathrm{P}, 15 \mathrm{~kg} \mathrm{ha}^{-1} \mathrm{~N}$ and $4.4 \mathrm{~kg} \mathrm{ha}^{-1} \mathrm{P}, 30 \mathrm{~kg} \mathrm{ha}^{-1} \mathrm{~N}$ and $13.2 \mathrm{~kg} \mathrm{ha}^{-1} \mathrm{P}$ respectively applied per year for 16 years as CAN and SSP fertilizer

b Low, medium, and high crop residue rates correspond to 300 , 900 , and $2700 \mathrm{~kg} \mathrm{ha}^{-1}$ crop residue added per year for 16 years. Manure rate is averaged for each combination of crop residue and fertilizer

c Means followed by the same letter are not significantly different $(p \geq 0.05)$ using Tukey test for LSD

\section{Effect of fertilizer rate on soil $\mathrm{N}$ and $\mathrm{P}$}

Manure and fertilizer interacted to significantly affect total $\mathrm{N}$ and $\mathrm{P}$, and available $\mathrm{P}$ (Table 3 ); however, only total $\mathrm{P}$ was affected by the interaction of crop residue and fertilizer (Table 4). Averaging the manure rates for each fertilizer rate, the reduced rate increased total $\mathrm{P}$ by $12 \%$ from the control, and the recommended rate was $20 \%$ higher than the control, with a $7 \%$ increase from the reduced rate. This indicates, as expected, that 
Table 3 Effect of fertilizer and manure treatment on soil total and available $\mathrm{P}$ and total $\mathrm{N}$ in the surface $(0-20 \mathrm{~cm})$ soil at the Sadore long-term research site

\begin{tabular}{|c|c|c|c|c|}
\hline Fertilizer & Manure & $\begin{array}{l}\text { Total P } \\
\left(\mathrm{mg} \mathrm{kg}^{-1}\right)\end{array}$ & $\begin{array}{l}\text { Available P } \\
\left(\mathrm{mg} \mathrm{kg}^{-1}\right)\end{array}$ & $\begin{array}{l}\text { Total N } \\
\left(\mathrm{mg} \mathrm{kg}^{-1}\right)\end{array}$ \\
\hline \multirow[t]{3}{*}{ Control $^{\mathrm{a}}$} & Low $^{\mathrm{b}}$ & $116.2 \mathrm{f}^{\mathrm{c}}$ & $4.2 \mathrm{e}$ & $111.6 b c$ \\
\hline & Medium & $142.7 \mathrm{de}$ & $6.7 \mathrm{de}$ & $95.9 \mathrm{cde}$ \\
\hline & High & $173.4 \mathrm{abc}$ & $6.7 \mathrm{de}$ & $80.6 \mathrm{e}$ \\
\hline \multirow[t]{3}{*}{ Reduced } & Low & 127.2ef & $9.2 \mathrm{de}$ & $120.7 b$ \\
\hline & Medium & $166.6 \mathrm{bc}$ & $10.7 \mathrm{cde}$ & $97.9 \mathrm{~cd}$ \\
\hline & High & $191.7 \mathrm{a}$ & $12.7 \mathrm{~cd}$ & $80.6 \mathrm{e}$ \\
\hline \multirow[t]{3}{*}{ Recommended } & Low & $152.0 \mathrm{~cd}$ & $30.8 \mathrm{a}$ & $138.3 \mathrm{a}$ \\
\hline & Medium & 180.0ab & $17.5 b c$ & $118.7 b$ \\
\hline & High & $186.8 \mathrm{ab}$ & $20.4 b$ & $124.1 \mathrm{ab}$ \\
\hline
\end{tabular}

${ }^{a}$ Control, reduced and recommended fertilizer rates correspond to $0 \mathrm{~kg} \mathrm{ha}^{-1} \mathrm{~N}$ and $0 \mathrm{~kg} \mathrm{ha}^{-1} \mathrm{P}, 15 \mathrm{~kg} \mathrm{ha}^{-1} \mathrm{~N}$ and $4.4 \mathrm{~kg} \mathrm{ha}^{-1} \mathrm{P}$, $30 \mathrm{~kg} \mathrm{ha}^{-1} \mathrm{~N}$ and $13.2 \mathrm{~kg} \mathrm{ha}^{-1} \mathrm{P}$ respectively applied per year for 16 years as CAN and SSP fertilizer

b Low, medium, and high manure rates correspond to 300, 900, and $2700 \mathrm{~kg} \mathrm{ha}^{-1}$ manure added per year for 16 years

${ }^{c}$ Means followed by the same letter are not significantly different $(p \geq 0.05)$ using Tukey test for LSD

Table 4 Effect of fertilizer and crop residue treatment on soil total $\mathrm{P}$ in the surface $(0-20 \mathrm{~cm}$ depth) soil at the Sadore longterm research site

\begin{tabular}{|c|c|c|}
\hline Fertilizer rate & $\begin{array}{l}\text { Crop residue } \\
\text { rate }\end{array}$ & $\begin{array}{l}\text { Total P } \\
\left(\mathrm{mg} \mathrm{kg}^{-1}\right)\end{array}$ \\
\hline \multirow[t]{3}{*}{ Control $^{\mathrm{a}}$} & Low $^{b}$ & $148.6 \mathrm{~cd}^{\mathrm{c}}$ \\
\hline & Medium & $135.4 d$ \\
\hline & High & $148.2 \mathrm{~cd}$ \\
\hline \multirow[t]{3}{*}{ Reduced } & Low & $149.0 \mathrm{~cd}$ \\
\hline & Medium & $168.6 \mathrm{abc}$ \\
\hline & High & $167.9 \mathrm{abc}$ \\
\hline \multirow[t]{3}{*}{ Recommended } & Low & $159.5 b c$ \\
\hline & Medium & $174.2 \mathrm{ab}$ \\
\hline & High & $185.1 \mathrm{a}$ \\
\hline
\end{tabular}

a Control, reduced and recommended fertilizer rates correspond to $0 \mathrm{~kg} \mathrm{ha}^{-1} \mathrm{~N}$ and $0 \mathrm{~kg} \mathrm{ha}^{-1} \mathrm{P}, 15 \mathrm{~kg} \mathrm{ha}^{-1} \mathrm{~N}$ and $4.4 \mathrm{~kg} \mathrm{ha}^{-1} \mathrm{P}, \quad 30 \mathrm{~kg} \mathrm{ha}^{-1} \mathrm{~N}$ and $13.2 \mathrm{~kg} \mathrm{ha}^{-1} \mathrm{P}$ respectively applied per year for 16 years as CAN and SSP fertilizer

b Low, medium, and high crop residue rates correspond to 300 , 900 , and $2700 \mathrm{~kg} \mathrm{ha}^{-1}$ crop residue added per year for 16 years

c Means followed by the same letter are not significantly different $(p \geq 0.05)$ using Tukey test for LSD

the majority of the applied fertilizer is either being taken up by plants or lost via erosion/leaching. Manure rate appears to influence total soil $\mathrm{P}$ levels more than fertilizer rate, as the high manure rate treatments had the highest total $\mathrm{P}$ concentration regardless of fertilizer rate.

When the available $\mathrm{P}$ results in Table 3 for each fertilizer rate are averaged across all manure rates, the recommended rate significantly increased available $\mathrm{P}$ by $290 \%$ of the control (22.9 vs. 5.9). Interestingly, for the recommended fertilizer rate, available $\mathrm{P}$ was higher in the low than high manure rate. Variation in total $\mathrm{N}$ was much smaller than $\mathrm{P}$, and was not significantly increased from the control to reduced rate, and was only increased by $27 \%$ from the reduced to recommended rate. For all fertilizer rates, manure application was inversely related to total $\mathrm{N}$, which was unexpected. Possible explanations for this could be that addition of manure along with $\mathrm{N}$ and $\mathrm{P}$ fertilizer adds micronutrients and base cations not added in fertilizer (Bayu et al. 2004), which may increase yield and $\mathrm{N}$ uptake. Soil $\mathrm{N}$ may also be lower with a higher manure rate because manure may stimulate organic $\mathrm{N}$ mineralization and nitrification of released ammonia (Müller et al. 2003).

Crop residue and fertilizer affected total $\mathrm{P}$ in the soils but not available P or total N (Table 4). Total P was highest under recommended fertilizer and the high rate of crop residue and levels decreased with decreasing fertilizer and crop residue application rates. This is consistent with other studies that found crop residue did not impact available $\mathrm{P}$ with fertilizer application (Yamoah et al. 2002; Knewtson et al. 
2008). There may be no difference in total $P$ between crop residue application rates at lower fertilizer rates because plants are releasing extracellular phosphatase enzymes to mineralize $\mathrm{P}$ in crop residues to meet plant $\mathrm{P}$ demand (Reddy et al. 2000). A similar demandinduced solubilization of crop residue $\mathrm{P}$ was reported in other Sahel research (Hafner et al. 1993). Crop residues may be useful for building up total soil $\mathrm{P}$ levels, but fertilizer application is necessary for total $\mathrm{N}$ and available $\mathrm{P}$ supply.

\section{$\mathrm{C}$ and $\mathrm{N}$ speciation}

$\mathrm{C}$ and $\mathrm{N}$ K-edge XANES results give valuable insight into how the reduced fertilizer rate and $\mathrm{OM}$ inputs are may be influencing SOM formation and mineralization in the Sahel. The results from the C XANES analysis of treatments (Fig. 2) show differences between treatments in aromatics (peak 1), carboxyls (peak 4), and carbohydrates, (peak 5), with minimal differences in ketones (peak 2) and phenols (peak 3). For Figs. 2 and 3, the input types and rates are codified as: $\mathrm{R}=$ residue, $\mathrm{F}=$ fertilizer and $\mathrm{M}=$ manure, and $0=$ low organic/control fertilizer application, $1=$ medium organic/microdose fertilizer application and $2=$ high organic/recommended fertilizer application. Carbohydrate content (Fig. 2, peak 5) increased with increasing fertilizer input (i.e., F2), with the highest in the treatment with greatest fertilizer input and lowest OM input (ROF2M0). There is an interaction between fertilizer and organic inputs on carbohydrate content. It is likely that the yield and biomass increase offered by fertilizer inputs results in increased root residue carbohydrate input. Manure nutrient input in R2F2M2, however, appears to

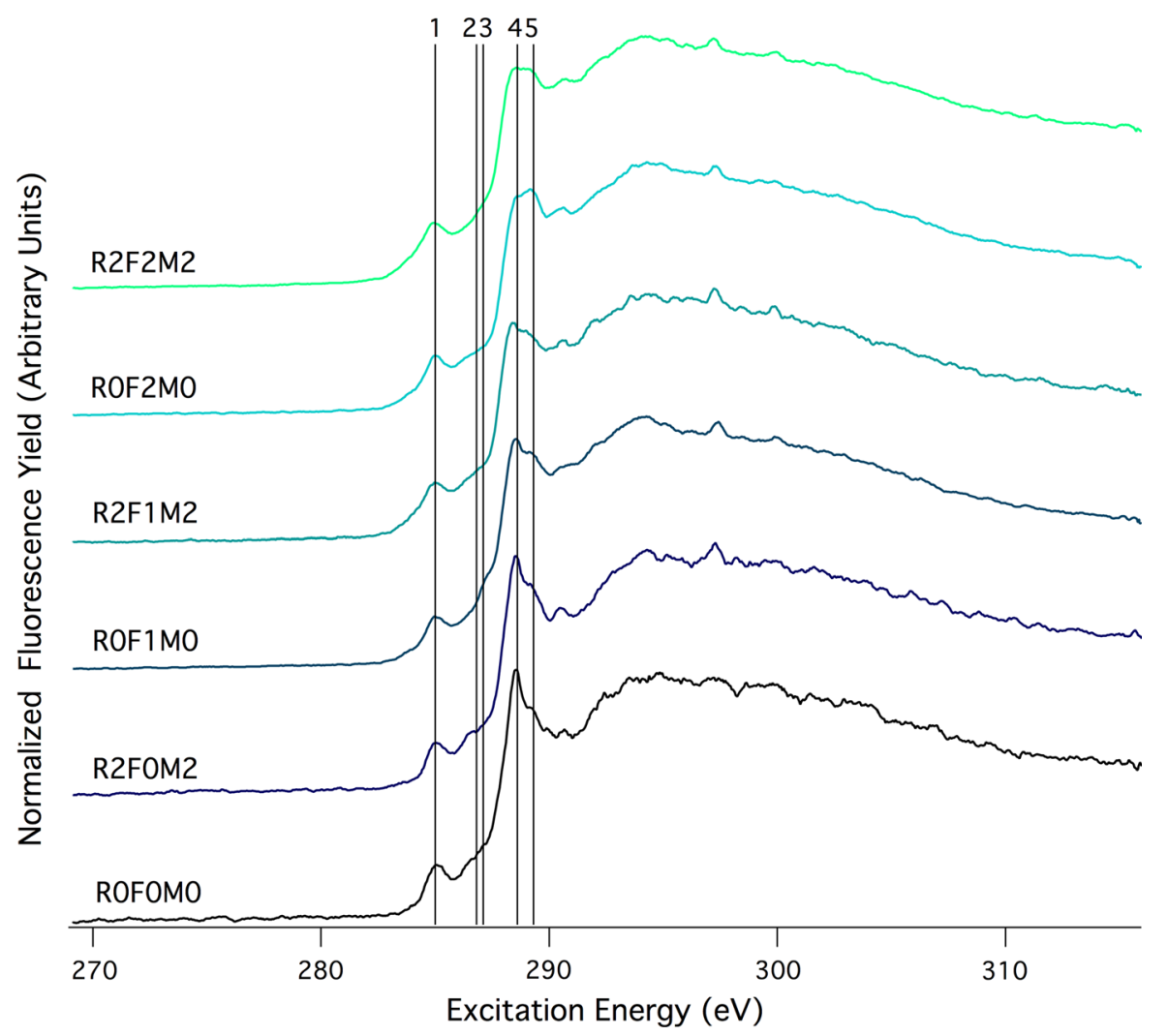

Fig. 2 Normalized fluorescence yield of C $K$-edge XANES spectra of soils at Sadore by fertilizer treatment in combination with varying organic amendment rates. $\mathrm{R}=$ residue, $\mathrm{F}=$ fertilizer, $\mathrm{M}=$ manure; $\mathrm{F} 0=$ control, $\mathrm{F} 1=$ reduced rate, $\mathrm{F} 2=$ recommended rate; $\mathrm{R} 0$ and $\mathrm{M} 0=300 \mathrm{~kg} \mathrm{ha}^{-1}$ rate, $\mathrm{R} 1$ and $\mathrm{M} 1=900 \mathrm{~kg} \mathrm{ha}^{-1}$ rate, $\mathrm{R} 2$ and M2 $=2700 \mathrm{~kg} \mathrm{ha}^{-1}$ rate. Carbon features corresponding to specific excitation energy are identified as: 1 . aromatic-C at $285 \mathrm{eV} ; 2$. ketones at $286.8 \mathrm{eV} ; 3$. phenolic at $287.1 \mathrm{eV} ; 4$. carboxylic at $288.6 \mathrm{eV} ; 5$. carbohydrate hydroxyl at $289.6 \mathrm{eV}$ 
Fig. 3 Normalized fluorescence yield of $\mathrm{N} K$ edge XANES spectra of soils at Sadore by fertilizer treatment in combination with varying intensities of organic amendments. Abbreviations of soil treatments are same as for Fig. 2. Nitrogen features corresponding to specific excitation energy are identified as: 1 . pyridines and pyrazines, aromatic $\mathrm{N}$ in 6-membered rings at $398.8 \mathrm{eV}$; 2. amide at $401.2 \mathrm{eV}$; 3. pyrrolic, $\mathrm{N}$ in 5 -membered rings with unpaired electrons, at $402.5 \mathrm{eV}$; 4. N-bonded aromatics at 403.5$403.8 \mathrm{eV} ; 5$. nitrate $\mathrm{N}$ at $405.3 \mathrm{eV}$ 6. alkyl-N at $406 \mathrm{eV}$

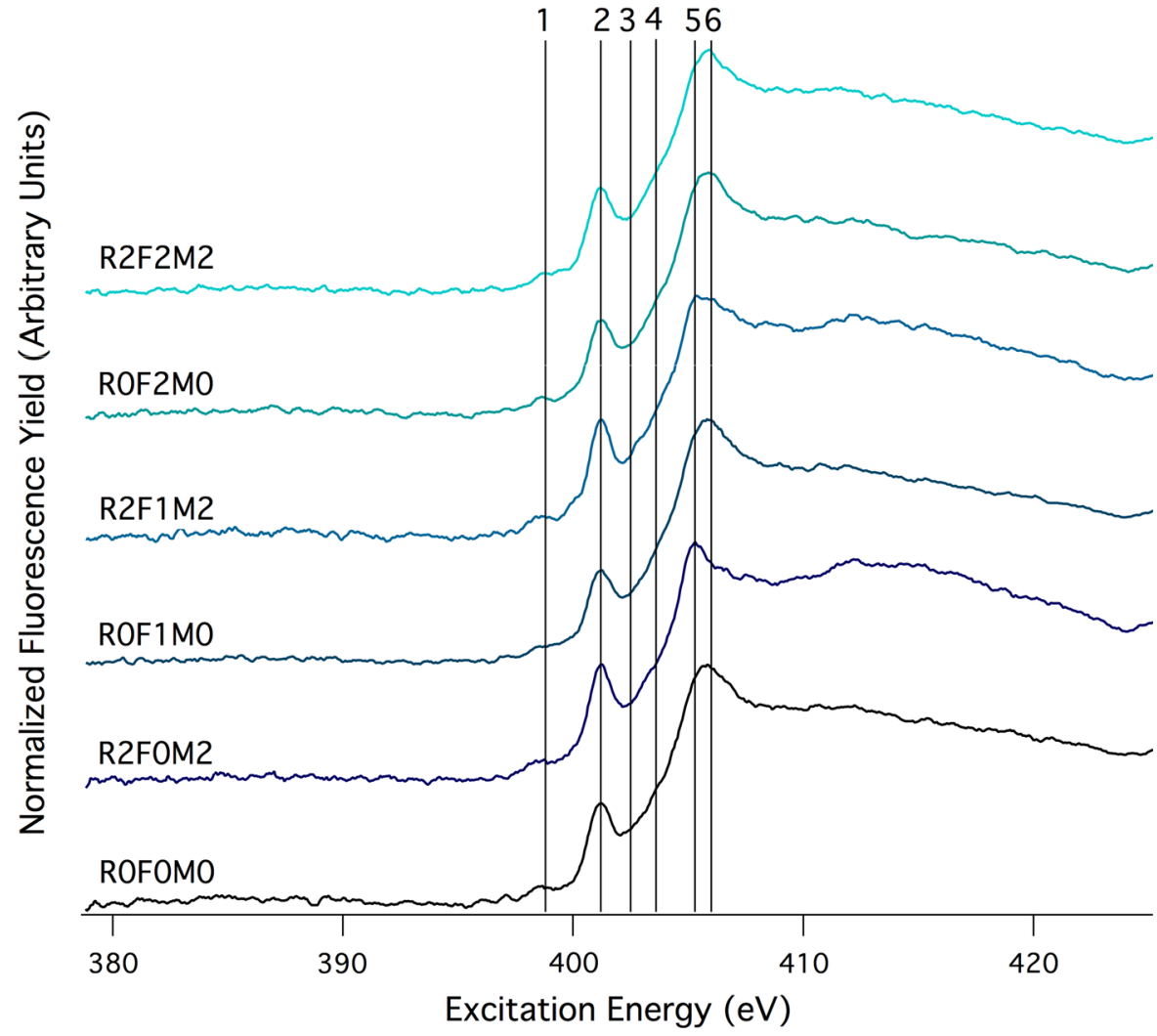

increase carbohydrate mineralization. Carbohydrates are a preferentially degraded carbon form, and are released from decomposing polysaccharides. Carbohydrate content tends to decrease as decomposition proceeds (Kögel-Knabner 2000; Gillespie et al. 2011). One study of temperate soils found that carbohydrates were lower in depleted soil where fertilizer was not applied, due to lower plant inputs and greater turnover of those inputs (Kiem et al. 2000).

In contrast with carbohydrates, which were most abundant with high fertilizer and low OM input, the opposite pattern was observed in aromatics and unsaturated C (Fig. 2, peak 1). The treatment with the highest rate of fertilizer, manure, and crop residue (R2F2M2) was highest in aromatics while the low organic + reduced fertilizer treatment (R0F1M0) and the high organic + control fertilizer (R2F0M2) treatment were lowest. Aromatics in sandy soil are derived from the relative enrichment of lignin as decomposition proceeds and more labile compounds are broken down (Vinceslas-Akpa and Loquet 1997; Albrecht et al. 2015). A higher abundance of both organic and mineral fertilizer inputs is a dominant controller of aromatic abundance in our samples. This may be because higher fertilizer and OM rates lead to greater crop production and input of lignin-containing millet residues. Fertilizer amendment and nutrients in manure also stimulates the breakdown of more labile OM groups, which should increase the relative abundance of aromatics. Where both fertilizer and organic matter input were low, aromatics were also low, reflecting lack of both stimulant and substrate for $\mathrm{OM}$ cycling.

Carboxylic-C (Fig. 1, peak 4) was most abundant in treatments with lower fertilizer rates, regardless of $\mathrm{OM}$ rate. The control treatment (R0F0M0) was highest in carboxyl-C, followed by high OM amendment with no fertilizer (R2F0M2) and control OM amendment with reduced fertilizer rate (R0F1M0). R2F2M2, R2F1M2, and R0F2M0, which had the highest mineral fertilizer inputs, were lower in carboxyls. Carboxylic acids increase with decomposition and are found in plant material as carboxylic acids, as a component of 
proteins, and as a product of lignin transformation, as well as in microbial matter (Kögel-Knabner 2002; Mahieu et al. 2000). Carboxyl groups are more resistant against further degradation and their presence represents a higher degree of oxidation (Kiem et al. 2000). With low fertilizer application, one would expect slower decomposition of lignin and thus lower production of carboxyl groups. However, low nutrient availability may also reduce microbial decomposition of carboxyl-containing organic groups that have already formed through humification in more oxidized soils.

The $\mathrm{N}$ functional groups varying in abundance between treatments are amide-, pyrrolic-, nitrate-, and alkyl-N (Fig. 3). Pyrrolic-N (Fig. 3, peak 3), was higher with greater addition of OM under the control or reduced fertilizer treatments (R2F1M2, R2F0M2, R2F2M2, R0F0M0) and was lowest in the R0F1M0 and R0F2M0 treatments where fertilizer inputs were higher than organic matter inputs. Results indicate that a higher amount of inorganic $\mathrm{N}$ fertilizer compared to OM addition stimulates pyrrolic break down. Pyrrolics are heterocyclic plant compounds formed through reaction of inorganic $\mathrm{N}$ with organic matter and they generally increase with degree of decomposition (Mahieu et al. 2000; Vairavamurthy and Wang 2002). Heterocyclic N compounds are produced earlier in the OM decomposition pathway and they typically persist throughout breakdown (Vairavamurthy and Wang 2002). In the current research, however, pyrrolics do not persist with greater $\mathrm{N}$-inputs, which may be due to climate (leaching) or soil mineralogy of this site. Under finer-textured soil, pyrollics persist in treatments higher in fertilizer $\mathrm{N}$ due to adsorption and aggregation that protects them from microbial degradation; in the sandy soil of Sadore, these processes may be limited in importance.

The four treatments that were highest in pyrrolics were also high in amides (Fig. 3, peak 2), and the two treatments lowest in pyrrolics, (R0F1M0 and R0F2M0) were also lowest in amides. Amides are components of protein that generally decrease in abundance over time because they are a readily accessible source of $\mathrm{N}$ for microbes (Gillespie et al. 2014a; Albrecht et al. 2015). Amides may become lower as amount of fertilizer $\mathrm{N}$ addition increases and organic input decreases because $\mathrm{N}$ is stimulating decomposition (Appel and Mengel 1990). Accumulation of amides may largely be due to adsorption of proteins on mineral surfaces (Gillespie et al. 2014a); in these soils there are few mineral surfaces for amide adsorption to occur. Thus amides are likely low because they are broken down with higher $\mathrm{N}$ addition. Amides may be higher in the R2F1M2 and R2F0M2 treatments than the R0F0M0 and R2F2M 2 treatments because greater organic $\mathrm{N}$ input would stimulate less amide breakdown.

The control fertilizer and high OM treatment (R2F0M2), which is abundant in amides and pyrrolics, is lower in alkyl-N, (Fig. 3, peak 6), compared to all other treatments, indicating alkyl-N may build up as amides and pyrrolics break down. Alkyl-N may be low when amides are highest because amides must break down to form alkyl-N (Sjorgersten et al. 2003). Another important observation is that the alkyl-N peaks for R2F0M2 and R2F1M2, the treatments highest in organic matter as well as amides, are shifted to the left (Fig. 3, peak 5) indicating that more $\mathrm{N}$ in these two samples is in the nitrate form relative to ammonium (Leinweber et al. 2007). Addition of crop residue and/or manure may be stimulating nitrification; this was seen in another long-term research trial where increased manure application led to increased $\mathrm{NO}_{3}{ }^{-}$production and higher nitrification rates (Müller et al. 2011).

In contrast with the above $\mathrm{C}$ and $\mathrm{N}$ groups, there was no difference between fertility treatments in ketone-C or phenol-C abundance (Fig. 2). There may be no difference in phenols, which are recalcitrant plant derived compounds found in lignin (Grandy and Neff 2008; Wickings et al. 2012), due to a combination of factors. First, there is a strong similarity of plant biomass in all cases (millet), which may lead to the same abundance of phenols regardless of treatment. Secondly, phenols may not be retained in the soil because kaolinite, the dominant mineral in these soils, does not typically adsorb phenol groups (Asselman and Garnier 2000). There was also no difference among treatments in ketones, which are present in microbial material and produced through microbial metabolism of aromatic and fatty acid compounds (Gottschalk 1986; Dent et al. 2004; Hitchcock et al. 2009). Ketones are mainly retained in the fine mineral fraction (Gillespie et al. 2014a), which is very small at Sadore. Overall, low soil organic carbon content in this study may largely be explained by the lack of a fine soil fraction to adsorb organic polymers and protect SOM. 


\section{Conclusions}

This study demonstrates that there are both benefits and drawbacks to using the reduced fertilizer rates in the Sahel. The reduced fertilizer rate increases soil $\mathrm{N}$ and $\mathrm{P}$ concentration compared to not adding fertilizer, but not to the same extent as the recommended rate. Soil acidification is less severe in reduced rate samples compared to recommended rates of fertilizer application. Drawbacks to the reduced rate of fertilizer compared to the recommended rate include lower yields and slightly lower soil organic carbon. Based on the decline in yield trend over 16 years for the reduced and recommended fertilizer rates, neither fertilizer rate can be considered truly sustainable. However, crop residue and manure additions improve the sustainability of reduced fertilizer additions by buffering $\mathrm{pH}$, improving total $\mathrm{P}$, supplying essential plant nutrients that inorganic fertilizer does not. Based upon this, our recommendation to smallholder farmers would be to utilize fertilizer microdosing in concert with organic amendments to optimize productivity.

Surprisingly, even 16 years of large amounts of organic inputs did not substantially increase SOC; this may be due to limited adsorption and aggregation in sandy Sadore soils and rapid turnover rates for organic inputs. XANES provided some novel insights into how $\mathrm{C}$ and $\mathrm{N}$ are cycling in these soils: treatments with low fertilizer rates and higher organic inputs were enriched in more labile or plant-derived $\mathrm{C}$ and $\mathrm{N}$, whereas the high fertilizer rates and low organic inputs had evidence of greater SOM breakdown. The arid climate and sandy soil of Sadore also resulted in unexpected C and $\mathrm{N}$ chemistry, as organic groups that are normally protected via adsorption, including aromatic-, phenoland ketone-C, and pyrrolic-N, were depleted at Sadore because higher fertilizer inputs favored decomposition. Rates of crop residue and manure much higher than those applied in the current research are required to increase $\mathrm{pH}$, SOC levels and stabilize yields in this region. Alternatively, since turnover rates appear to be quite rapid and mineralization is high for soil carbon, it may be more efficient to manage SOC inputs more intensively (timing, incorporation approaches, choice of inputs) rather than increasing the quantities applied.

Acknowledgments International Development Research Centre, the Government of Canada through Foreign Affairs, Trade and Development Canada, and the National Science and
Engineering Research Council, funded this research. As well, research described in this paper was performed at the Canadian Light Source, which is supported by the Canada Foundation for Innovation, Natural Sciences and Engineering Research Council of Canada, the University of Saskatchewan, the Government of Saskatchewan, Western Economic Diversification Canada, the National Research Council Canada, and the Canadian Institutes of Health Research. The authors would also like to thank IDRC Program Officers Drs. Kevin Tiessen and Innocent Butare for their inputs throughout the research.

\section{Compliance with ethical standards}

Conflict of interest The authors declare they have no conflict of interest.

Open Access This article is distributed under the terms of the Creative Commons Attribution 4.0 International License (http:// creativecommons.org/licenses/by/4.0/), which permits unrestricted use, distribution, and reproduction in any medium, provided you give appropriate credit to the original author(s) and the source, provide a link to the Creative Commons license, and indicate if changes were made.

\section{References}

Abdoulaye T, Sanders JH (2005) Stages and determinants of fertilizer use in semiarid African agriculture: the Niger experience. Agric Econ 32:167-179

Akponikpe PBI, Michels K, Bielders CL (2008) Integrated nutrient management of pearl millet in the Sahel combining cattle manure, crop residue and mineral fertilizer. Exp Agric 44(4):453-472

Albrecht R, Sebag D, Verrecchia E (2015) Organic matter decomposition: bridging the gap between Rock-Eval pyrolysis and chemical characterization (CPMAS 13C NMR). Biogeochemistry 122:101-111

Alvarez R (2005) A review of nitrogen fertilizer and conservation tillage effects on soil organic carbon storage. Soil Use Manag 21:38-52

Appel T, Mengel K (1990) Importance of organic nitrogen fractions in sandy soils, obtained by electro-ultrafiltration or $\mathrm{CaCl}_{2}$ extraction, for nitrogen mineralization and nitrogen uptake of rape. Biol Fertil Soils 10:97-101

Asselman T, Garnier G (2000) Adsorption of model wood polymers and colloids on bentonites. Colloid Surf A 168:175-182

Aune JB, Bationo A (2008) Agricultural intensification in the Sahel-the ladder approach. Agric Syst 98(2):119-125

Aune JB, Ousman A (2011) Effect of seed priming and microdosing of fertilizer on sorghum and pearl millet in Western Sudan. Exp Agric 47(3):419-430

Bado BV, Bationo A, Lompo F, Traore K, Sedogo MP, Cescas MP (2012) Long term effects of crop rotations with fallow or groundnut on soil fertility and succeeding sorghum yields in the Guinea savannah of West Africa. In: Bationo A et al (eds) Lessons learned from long-term soil fertility 
management experiments in Africa. Springer, Dordrecht, pp $27-40$

Bagayoko M, Maman N, Palé S, Sirifi S, Taonda SJB, Traore S, Mason SC (2011) Microdose and N and P fertilizer application rates for pearl millet in West Africa. Afr J Agric Res 6(5):1141-1150

Bationo A, Kihara J, Vanlauwe B, Waswa B, Kimetu J (2007) Soil organic carbon dynamics, functions and management in West African agro-ecosystems. Agric Syst 94:13-25

Bationo A, Hartemink A, Lungu O, Naimi M, Okoth P, Smaling E, Thiombiano L, Waswa B (2012) Knowing the African soils to improve fertilizer recommendations. In: Kihara J et al (eds) Improving soil fertility recommendations in Africa using the decision support system for agrotechnology transfer (DSSAT). Springer, Dordrecht, pp 19-42

Bayu W, Rethman NFG, Hammes PS (2004) The role of animal manure in sustainable soil fertility management in subSaharan Africa: a review. J Sustain Agric 25(2):113-136

Caires EF, Haliski A, Bini AR, Scharr DA (2015) Surface liming and nitrogen fertilization for crop grain production under no-till management in Brazil. Euro J Agron 66:41-53

Chauvin NP, Mulangu FM, Porto G (2012) Food production and consumption trends in sub-Saharan Africa: prospects for the transformation of the agricultural sector. Working paper. United Nations Development Program, Regional Bureau for Africa

Chivenge P, Vanlauwe B, Six J (2010) Does the combined application of organic and mineral nutrient sources influence maize productivity? A meta-analysis. Plant Soil 342:1-30

Dent BB, Forbes SL, Stuart BH (2004) Review of human decomposition processes in soil. Environ Geol 45:576-585

Feller C, Beare MH (1997) Physical control of soil organic matter dynamics in the tropics. Geoderma 79(1):69-116

Geiger SC, Manu A, Bationo A (1992) Changes in a sandy Sahelian soil following crop residue and fertilizer additions. Soil Sci Soc Am J 56:172-177

Gentile RM, Vanlauwe B, Six J (2013) Integrated soil fertility management: aggregate carbon and nitrogen stabilization in differently textured tropical soils. Soil Biol Biochem 67:124-132

Gillespie AW, Walley FL, Farrell RE, Regier TZ, Blyth RIR (2008) Calibration method at the N K-edge using interstitial nitrogen gas in solid-state nitrogen-containing inorganic compounds. J Synchrotron Radiat 15:532-534

Gillespie AW, Walley FL, Farrell RE, Leinweber P, Eckhardt KU, Regier TZ et al (2011) XANES and pyrolysis-FIMS evidence of organic matter composition in a Hummocky landscape. Soil Sci Soc Am J 75(5):1741-1755

Gillespie AW, Diochon A, Ma BL, Morrison MJ, Kellman L, Walley FL et al (2014a) Nitrogen input quality changes the biochemical composition of soil organic matter stabilized in the fine fraction: a long-term study. Biogeochemistry 117(2-3):337-350

Gillespie AW, Sanei H, Diochon A, Ellert BH, Regier TZ, Chevrier D et al (2014b) Perennially and annually frozen soil carbon differ in their susceptibility to decomposition: analysis of Subarctic earth hummocks by bioassay, XANES and pyrolysis. Soil Biol Biochem 68:106-116

Gillespie AW, Phillips CL, Dynes JJ, Chevrier D, Regier TZ, Peak D (2015) Advances in using soft X-ray spectroscopy for measurement of soil biogeochemical processes. Adv Agron 113:1-32

Gottschalk G (1986) Bacterial metabolism, 2nd edn. Springer, New York

Grandy AS, Neff JC (2008) Molecular C dynamics downstream: the biochemical decomposition sequence and its impact on soil organic matter structure and function. Sci Total Environ 404:297-307

Hafner H, George E, Bationo A, Marschner H (1993) Effect of crop residues on root growth and phosphorus acquisition of pearl millet in an acid sandy soil in Niger. Plant Soil 150:117-127

Hendershot WH, Lalonde H, Duquette M (2008) Soil reaction and exchangeable acidity. In: Carter MR, Gregorich EG (eds) Soil sampling and methods of analysis. CRC Press, Boca Raton, pp 173-178

Hitchcock AP, Dynes JJ, Lawrence JR, Obst M, Swerhone GDW, Korber DR et al (2009) Soft X-ray spectromicroscopy of nickel sorption in a natural river biofilm. Geobiology 7:432-453

Janssen BH (2011) Simple models and concepts as tools for the study of sustained soil productivity in long-term experiments. I. New soil organic matter and residual effect of $P$ from fertilizers and farmyard manure in Kabete, Kenya. Plant Soil 339(1-2):3-16

Jones A, Breunin-Madsen H, Brossard M, Dampha A, Deckers J, Dewitte O et al (2013) Soil Atlas of Africa. European Commission, Publications Office of the European Union, Luxembourg

Kibunja CN, Mwaura FB, Mugendi DN, Gicheru PT, Wamuongo JW, Bationo A (2012) Strategies for maintenance and improvement of soil productivity under continuous maize and beans cropping system in the sub-humid highlands of Kenya: case study of the long-term trial at Kabete. In: Bationo A et al (eds) Lessons learned from long-term soil fertility management experiments in Africa. Springer, Dordrecht

Kiem R, Knicker H, Körschens M, Kögel-Knabner I (2000) Refractory organic carbon in C-depleted arable soils, as studied by 13C NMR spectroscopy and carbohydrate analysis. Org Geochem 31:655-668

Kihanda FM, Warren GP (2012) Management of soil fertility in a long-term field trial of semi-arid Kenya. In: Bationo A et al (eds) Lessons learned from long-term soil fertility management experiments in Africa. Springer, Dordrecht

Knewtson SJB, Hons FM, Juo ASR, Hossner LR (2008) Cropping system effects and seasonal dynamics of extractable phosphorus in a semi-arid soil of the Sahel, West Africa. Commun Soil Sci Plant Anal 39(1-2):217-230

Kögel-Knabner I (2000) Analytical approaches for characterizing soil organic matter. Org Geochem 31:609-625

Kögel-Knabner I (2002) The macromolecular organic composition of plant and microbial residues as inputs to soil organic matter. Soil Biol Biochem 34:139-162

Lehmann J, Kleber M (2015) The contentious nature of soil organic matter. Nature 528:60-68

Leinweber P, Kruse J, Walley FL, Gillespie A, Eckhardt KU, Blyth RIR, Regier T (2007) Nitrogen K-edge XANES-an overview of reference compounds used to identify "unknown" organic nitrogen in environmental samples. J Synchrotron Radiat 14:500-511 
Leinweber P, Kruse J, Walley F, Gillespie A, Eckhardt KU, Blyth RIR, Regier TZ (2010) Nitrogen compounds in dissolved and solid environmental samples. In: Singh B, Gräfe $M$ (eds) Synchrotron-based techniques in soils and sediments, developments in soil science. Elsevier, New York, pp 255-288

Mahieu N, Olk DC, Randall EW (2000) Accumulation of heterocyclic nitrogen in humified organic matter: a $15 \mathrm{~N}$ NMR study of lowland rice soils. Eur J Soil Sci 51:379-389

Manna MC, Swarup A, Wanjari RH, Ravankar HN, Mishra B, Saha MN et al (2005) Long-term effect of fertilizer and manure application on soil organic carbon storage, soil quality and yield sustainability under sub-humid and semiarid tropical India. Field Crop Res 93(2-3):264-280

Müller C, Stevens RJ, Laughlin RJ (2003) Evidence of carbon stimulated $\mathrm{N}$ transformations in grassland soil after slurry application. Soil Biol Biochem 35:285-293

Müller C, Laughlin RJ, Christie P, Watson CJ (2011) Effects of repeated fertilizer and cattle slurry applications over 38 years on $\mathrm{N}$ dynamics in a temperate grassland soil. Soil Boil Biochem 43:1362-1371

Myneni SC (2002) Soft X-ray spectroscopy and spectromicrosopy studies of organic molecules in the environment. In: Fenter P, Rivers M, Sturchio N, Sutton S, Ribbe PH (eds) Applications of synchrotron radiation in low-temperature geochemistry and environmental science, reviews in mineralogy and geochemistry. Mineral Soc Am, Washington, DC, pp 485-579

Nakamura S, Hayashi K, Omae H, Fatondji D, Tabo R, Shinjo H et al (2012) Rothamsted carbon model reveals technical options to maintain soil organic carbon under semi-arid climate. Agron Sust Dev 32:865-872

Ouédraogo E, Mando A, Brussaard L, Stroosnijder L (2007) Tillage and fertility management effects on soil organic matter and sorghum yield in semi-arid West Africa. Soil Tillage Res 94(1):64-74

Reddy DD, Subbarao A, Rupa TR (2000) Effects of continuous use of cattle manure and fertilizer phosphorus on crop yields and soil organic phosphorus in a Vertisol. Bioresour Technol 75:113-118

Sime G, Aune JB (2014) Maize response to fertilizer dosing at three sites in the Central Rift Valley of Ethiopia. Agronomy 4:436-451
Sjorgersten S, Turner BL, Mahieu N, Condron LM, Wookey PA (2003) Soil organic matter biochemistry and potential susceptibility to climatic change across the forest-tundra ecotone in the Fennoscandian Mountains. Glob Change Biol 9:759-772

Thomas RL, Sheard RW, Moyer JR (1967) Comparison of conventional and automated procedures for $\mathrm{N}, \mathrm{P}$, and $\mathrm{K}$ analysis of plant material using a single digestion. Agron $\mathrm{J}$ 59:240-243

Twomlow S, Mugabe FT, Mwale M, Delve R, Nanja D, Carberry $\mathrm{P}$ et al (2008) Building adaptive capacity to cope with increasing vulnerability due to climatic change in Africa- a new approach. Phys Chem Earth 33:780-787

Urquhart SG, Ade H (2002) Trends in the carbonyl core (C $1 \mathrm{~s}$, O 1 s) \& \#xF0E0; pi ${ }^{*} \mathrm{c}=\mathrm{o}$ transition in the near-edge $\mathrm{X}$-ray absorption fine structure spectra of organic molecules. J Phys Chem B 106:8531-8538

Vairavamurthy A, Wang S (2002) Organic nitrogen in geomacromolecules: insights on speciation and transformation with K-edge XANES spectroscopy. Environ Sci Technol 36:3050-3056

Vanlauwe B, Kihara J, Chivenge P, Pypers P, Coe R, Six J (2010) Agronomic use efficiency of $\mathrm{N}$ fertilizer in maizebased systems in sub-Saharan Africa within the context of integrated soil fertility management. Plant Soil 339(1-2): 35-50

Vinceslas-Akpa M, Loquet M (1997) Organic matter transformations in lignocellulosic waste products composted or vermicomposted (Eisenia fetida andrei): chemical analysis and 13C CPMAS NMR spectroscopy. Soil Biol Biochem 29(3-4):751-758

Wickings K, Grandy AS, Reed SC, Cleveland CC (2012) The origin of litter chemical complexity during decomposition. Ecol Lett 15:1180-1188

World Bank (2014) Data. http://data.worldbank.org. Accessed 20 Nov 2014

Yamoah CF, Bationo A, Shapiro B, Koala S (2002) Trend and stability analyses of millet yields treated with fertilizer and crop residues in the Sahel. Field Crops Res 75:53-62

Ziadi N, Tran TS (2008) Mehlich 3-extractable elements. In: Carter MR, Gregorich EG (eds) Soil sampling and methods of analysis. CRC Press, Boca Raton, pp 81-88 